\title{
Stressed-out, or in (utero)?
}

\author{
Sarit Avishai-Eliner, \\ Dept of Anatomy and Neurobiology, University of California at Irvine, Irvine, CA 92697, USA and \\ Hebrew University, Jerusalem, and Kaplan Medical Center, Rehovoth, Israel 76100 \\ Kristen L. Brunson, \\ Dept of Anatomy and Neurobiology and Dept of Pediatrics, University of California at Irvine, Irvine, \\ CA 92697-4475, USA
}

Curt A. Sandman, and

Dept of Psychiatry, University of California at Irvine, Irvine, CA 92697, USA

Tallie Z. Baram*

Dept of Anatomy and Neurobiology and Dept of Pediatrics, University of California at Irvine, Irvine, CA 92697-4475, USA

\section{Abstract}

The molecular and cellular mechanisms by which plasticity is induced in the mature CNS (and, specifically, in the hippocampus) by environmental input are progressively being elucidated. However, the mechanisms - and even the existence - of functional and structural effects of environmental input (and, particularly, stress) early in life are incompletely understood. Here, we discuss recent evidence that stressful stimuli have a significant impact on neonatal (rat) and prenatal (human) hippocampal function and integrity. Stressful signals provoke expression and release of neuromodulators, including the peptide corticotropin-releasing hormone (CRH), leading to activation of CRH receptors on principal hippocampal neurons. Although physiological activation of these receptors promotes synaptic efficacy, pathological levels of CRH at hippocampal synapses contribute to neuronal death. Thus, early-life stress could constitute a 'double-edged sword': mild stress might promote hippocampal-dependent cognitive function, whereas severe stress might impair neuronal function and survival, both immediately and in the long-term. Importantly, these CRHmediated processes could be targets of preventive and interventional strategies.

The ability of an organism to adapt to its environment is integral to its survival [1]. Daily life involves confrontation with changing situations that can be physiologically or psychologically challenging. To cope with these 'physical or perceived threats to homeostasis' (an operational definition of 'stress') [2], the ability to alter function and expression of neuronal genes has been developed in the form of molecular and behavioral stress responses. This is advantageous because it allows rapid behavioral, autonomic and cognitive CNS responses to stressful circumstances, followed by prompt re-establishment of the functional steady state. Therefore, upon sensing stress, our brain not only initiates rapid secretion of effector molecules (noradrenaline and adrenal glucocorticoids), but also responds to the inciting signal with patterned and coordinated changes in programmed gene expression $[1,3,4]$.

These responses to stress are a 'double-edged sword' [5]. While enhancing neuronal communication and promoting survival, they can impact upon neuronal function and integrity, both immediately and in the long-term. Consequences of stress, such as its negative influences

‘tallie@uci.edu. 
on cognition and emotional stability, are an issue of major relevance to human health: chronic and/or severe activation of the stress response early in life has been shown to be potentially injurious in both humans (reviewed in Refs [3,6,7]) and experimental animals $[3,4,5,8]$. Indeed, via complex interactions with genetic factors [3], early-life events could be a major determinant of the smaller brain volume and long-term cognitive dysfunction in pre-term infants $[9,10]$, and might play a role in certain affective and dementia disorders in the adult and aging human $[1,3,4]$. Not surprisingly, mechanisms protecting the immature brain from potentially injurious effects of early stress have been delineated [11].

The mechanisms by which early-life stress provokes these long-term effects remain unresolved but evidence for persistent organizational changes ('programming') in CNS stress responses has been building [3,7]. Gaining insight into the biological underpinnings of the consequences of early-life stress requires understanding of the age-specific processes activated by stressful stimuli at the molecular, cellular and circuit levels. Here we focus on novel and evolving concepts regarding the potential mechanisms underlying the short and long-term effects of early-life stress on hippocampal function (e.g. learning and memory) and integrity. Molecular events triggered by stress are highlighted, with emphasis on corticotropin-releasing hormone (CRH), a key stress-activated modulator of limbic neuronal function. We describe recent data showing that administration of $\mathrm{CRH}$ to the brains of immature rats reproduces the consequences of severe early-life stress, leading to progressive loss of neurons from the CA3 region of the hippocampus and impaired memory functions throughout life [4]. We also describe the effects of stress-induced $\mathrm{CRH}$, derived from the maternal placenta, on learning functions in the human fetus [12] and discuss their implications for the adverse outcomes observed in many pre-term human infants $[7,9,10]$.

\section{Neuronal circuits and mediators of the responses to stress in adult and immature brains}

\section{Stress-activated neuronal networks}

The stress-response network in mature and developing rodents and primates consists of several interlacing circuits (reviewed in Refs $[2,3,8]$ ). The first is neuroendocrine, comprising the hypothalamic-pituitary-adrenal axis, which is activated in immediate, short-term and longterm phases. Neurochemical (e.g. autonomic) signals conveying potential threats reach the hypothalamus, releasing CRH from neurons in the paraventricular nucleus (PVN) to influence rapid secretion of pituitary corticotropin [Adrenocorticotropic hormone (ACTH); Fig. 1a]. ACTH induces secretion of glucocorticoids from the adrenal glands, and these interact with specific glucocorticoid receptors (GRs) in the hippocampus and elsewhere in the CNS, shutting off the hormonal stress response and restoring a steady state [13,14]. Stress-induced secretion of ACTH and glucocorticoids requires $\mathrm{CRH}$ because it is abolished by administration of CRH antisera or antagonists $[15,16]$.

Proper function of both the activation and the de-activation ('shut-off') mechanisms of this hypothalamic-pituitary-adrenal loop is crucial for handling of acute stress and, importantly, for resumption of normal CNS function and avoidance of the injurious effects of prolonged exposure to high levels of glucocorticoids (reviewed in Refs [1,5,6]). This rapid functional regulation of the neuroendocrine stress network is even more crucial early in life, when persistent glucocorticoid exposure can impair growth and maturational processes [3,7,9]. Indeed, the presence of an intact, although stimulus-selective, neuroendocrine stress response has been demonstrated throughout the first two postnatal weeks in the rat [16-19], and this response is highly influenced by maternal sensory input [20-23]. In the human, secretion of glucocorticoids in response to stress and pain has been demonstrated in both pre-term and fullterm neonates [24]. 
Stress involving higher-order sensory processing activates limbic pathways that contribute to the 'central' stress circuit [25-27] (Fig. 1b). Substantial information, based on lesion-studies and analyses of immediate-early-gene expression following specific stressors, is available about the structures and pathways involved. For both the mature and neonatal rodent, these include the amygdala $[19,26]$ and, as shown more recently, the hippocampus [1,27], as well as prefrontal cortex. Thus, 'cognitive' or 'emotional' stress signals converge on the central nucleus of the amygdala (ACe), inducing immediate-early-gene expression (Fig. 2a,b) and influencing, for example, facilitation of memory consolidation [28]. From outflow nuclei of the amygdala [29] selected stress signals reach the hippocampal formation (probably via both mono- and polysynaptic projections), inducing neuronal immediate-early-gene expression [27] (Fig. 2c) and, as we discuss later, enhancing synaptic efficacy [30,31].

Although the structures comprising the limbic stress-circuit in both rodent and human are being progressively defined (using, in the human, novel functional imaging methods [32]), the identity of the neuromodulators acting on neurons of the amygdala and hippocampus during stress is not fully known. In addition to the established role of stress-induced plasma glucocorticoids $[1,13,30,33]$, CRH is emerging as a major mediator of the effects of stress on neuronal function in these regions. In both adult and developing brain, significant populations of CRH mRNA-expressing neurons reside in the ACe [34,35] (Fig. 3a) and hippocampus [34,36,37] (Fig. 3b, 3c). Stress activates expression of Fos and the gene encoding CRH in the $\mathrm{CRH}$-containing neurons of the ACe in mature and neonatal rat [19]. The crucial role for $\mathrm{CRH}$ in 'central' stress responses [38] is also supported by the abrogation of stress-induced behaviors by administration of CRH antagonists into the ACe [39].

It is likely that the stress-related role of hippocampal CRH is more pronounced during development. Although stress does not generally activate the scattered CRH-producing neurons in adult hippocampus (as measured by Fos expression), select stressful stimuli enhance $\mathrm{CRH}$ production and release [4,27] in the robust populations of CRH-positive interneurons that reside in the neonatal hippocampus [37,40] (Fig. 3b,c). Stress-induced CRH binds to CRH receptors on principal cells, eliciting Fos expression (Fig. 2b,c). In addition, the CRH-receptor subtype mediating the actions of the peptide on hippocampal principal neurons $\left(\mathrm{CRF}_{1}\right)$ is particularly abundant during the first two postnatal weeks [41]. Indeed, increased abundance of both CRH-positive neurons and receptor-bearing target cells in developing hippocampus (together with minimal expression of the CRH-binding protein) support significant and agespecific roles for hippocampal CRH in mediating the influences of stress on hippocampal function early in life.

The distribution of CRH-positive cells in human brain is also consistent with a role of the peptide in high-order cognitive and emotional processing of stress-signals. CRH is abundant in amygdala, hippocampus and limbic cortical areas [42], where it could enhance arousal and cognitive function. Interestingly, a marked reduction of CRH levels (and a 'compensatory' upregulation of cortical CRH receptors) occurs in demented individuals [42]. Evidence for CRH production in the human neonate derives from cerebrospinal fluid analyses $[43,44]$, and in older children comes from studies of human tissue demonstrating $\mathrm{CRH}$ and $\mathrm{CRF}_{1}$ in cortical areas [45]. Although the presence of CRH receptors has not been reported in human neonates, the behavioral effects of stress-governed placental CRH on the fetal brain indicate the likely presence of a functional CRH-signaling cascade.

\section{What is the 'rodent equivalent' of the fetal and pre-term human?}

Because of difficulties inherent in mechanistic human studies, much of the evidence discussed here derives from the immature rodent, and is correlated with available and emerging human data. Therefore, constraints on comparing CNS - and specifically hippocampal - maturation 
across these species merit discussion (Box 1). Table 1 provides our current understanding of the relative rates and stages of hippocampal development in human and rat. Primate information is provided to facilitate evaluation of important studies on the role of $\mathrm{CRH}$ in the consequences of early-life stress in monkeys [3].

\section{Box 1 \\ Comparative maturation rates of human, primate and rat hippocampal formations}

The developing brain can be viewed as overlapping sets of moving targets, which mature with variable velocities. In addition, the precise nature of these modules and their rates of development vary across species, so that inter-species correlations of brain development are only approximate. Older studies considered the brain as a whole, suggesting that the 57-day-old rat might be 'equivalent' to the human newborn [a,b]. More recent work recognized the different velocities and sequences of maturation of specific CNS regions in human, primate and rodent [c], suggesting that selective regional comparisons might be preferred. Therefore, Table 1 of the main text relies on recent reviews of structural and functional maturation of human and primate hippocampus [d,e] together with wellestablished neuroanatomical data on hippocampal maturational milestones in rodents. As evident from Table 1, analyses of pyramidal and granule cell genesis, and of the structural and functional maturation of synaptic communication (e.g. the mossy fiber-CA3 pyramidal cell synapse), provide useful information about the relative time-frames and rates of their maturation across species. Importantly, Table 1 demonstrates that, even though comparative analyses limited to the hippocampal formation cannot provide precise correlation of human and rodent 'ages', they do suggest that the first week of life (or days 0-5) in rats might be comparable to the third trimester gestational period of humans. The first year of human life might correspond roughly to days 7-14 in the rat, with synaptic numbers peaking at the end of this period and remaining high through the second human year [f], and the 3 rd week of life in the rat $[\mathrm{g}, \mathrm{h}]$.

\section{References}

a. Dobbing J, Sands J. Comparative aspects of the brain growth spurt. Early Hum Dev 1979;3:79-83. [PubMed: 118862]

b. Gottlieb A, et al. Rodent brain growth stages: an analytical review. Biol Neonate 1977;32:166176. [PubMed: 603801]

c. Clancy B, et al. Translating developmental time across mammalian species. Neuroscience 2001;105:7-17. [PubMed: 11483296]

d. Herschkowitz N, et al. Neurobiological bases of behavioral development in the first year. Neuropediatrics 1997;28:296-306. [PubMed: 9453026]

e. Seress, L. Morphological changes in the human hippocampal formation from midgestation to early childhood. In: Nelson, CA.; Luciana, M., editors. Handbook of Developmental Cognitive Neuroscience. MIT Press; 2001. p. 45-58.

f. Herschkowitz N, et al. Neurobiological bases of behavioral development in the second year. Neuropediatrics 1999;30:221-230. [PubMed: 10598832]

g. Amaral DG, Dent JA. Development of the mossy fibers of the dentate gyrus: a light and electron microscopic study of the mossy fibers and their expansions. J Comp Neurol 1981;195:51-86. [PubMed: 7204652]

h. Ribak CE, et al. The development, ultrastructure and synaptic connections of the mossy cells of the dentate gyrus. J Neurocytol 1985;14:835-857. [PubMed: 2419523] 
With these considerations in mind, this review proceeds to focus on mechanisms of the acute and long-term effects of stress on limbic neuronal function in the neonatal [postnatal day $(\mathrm{P})$

0-P10] rat and third-trimester human fetus, with emphasis on the role of CRH.

\section{Sources of the $\mathrm{CRH}$ that acts on immature limbic neurons during stress}

\section{Human}

The human placenta expresses CRH mRNA as early as the seventh week of gestation [46], and the active peptide is released into the maternal circulation [47]. Indeed, later in pregnancy, $\mathrm{CRH}$ levels in maternal plasma reach those observed within only the hypothalamic-pituitary portal system during physiological stress, although the actions of CRH are tempered by its association with the CRH-binding protein [48]. Placental CRH is identical to human, and rat, hypothalamic CRH in structure, immunoreactivity and bioactivity [49] and the gene is highly conserved between these species [50].

However, regulation of CRH levels by stress, and particularly by stress-induced glucocorticoids, differs crucially between hypothalamus and placenta. In contrast to their negative control of the CRH promoter in both human and rat hypothalamus (Fig. 1a), glucocorticoids activate the CRH-gene promoter in placenta (Fig. 4). This establishes a positive feedback loop that permits simultaneous increase of plasma $\mathrm{CRH}$ and glucocorticoid levels throughout gestation $[49,51,52]$. Indeed, pathological amounts of CRH secreted from maternal and fetal placenta during subacute and chronic gestational stress [12,53] could penetrate the blood-brain barrier [54] and influence the function and integrity of hippocampal neurons.

Rat

In neonatal rat, the CRH acting on limbic synapses is derived from populations of CRHproducing neurons in amygdala and hippocampus [37,40] (rodent placenta does not produce $\mathrm{CRH})$. Whereas a single acute-stress event does not enhance $\mathrm{CRH}$ production in the amygdala of the immature rat, repeated acute stress leads to protracted upregulation of CRH mRNA expression in this region [19] via stress-induced activation of GRs [55]. It should be noted that enhanced expression of CRH follows typically the stress-induced release of the peptide ('compensatory upregulation'). This increased synthesis promotes augmented peptide release in response to the next stimulus [8].

As mentioned, the neonatal rat hippocampus harbors large numbers of CRH-containing cells (Fig. 3b,c), peaking at $18550 \pm 734$ on the 18th postnatal day versus $10729 \pm 1322$ in the far larger adult hippocampal formation [40]. Many of these CRH-producing neurons are strategically located basket and chandelier cells in the pyramidal and granule cell layers, synapsing directly onto the somata and axon initial-segments of principal neurons $[37,40]$. Acute stressful stimuli that activate the hippocampus (as determined using electrophysiology or Fos expression) also lead to transient (24-48 h) upregulation of CRH mRNA levels in the hippocampal formation [26,27]. The effects of sustained (chronic) stress in the neonatal rat on $\mathrm{CRH}$ abundance in the hippocampus are the focus of current investigations [4].

\section{Effects of CRH on the immature hippocampus}

Studies in humans indicate that prenatal exposure to CRH could influence learning and memory acutely. Fetuses of mothers with chronically elevated plasma CRH levels were less capable of distinguishing repeated tones from novel ones [12,53], suggesting that abnormal or excessive activation of $\mathrm{CRH}$ receptors in the limbic regions involved in learning and memory might impair these functions. Similar studies demonstrated that human fetuses between 28-34 weeks gestational age have attenuated startle responses after the administration of a synthetic glucocorticoid (betamethasone) to the mother [56], a treatment which should also enhance 
placental synthesis and release of CRH [49,51,52]. Human studies such as these cannot distinguish between direct effects of CRH on hippocampal neurons and those effects that might result from CRH-induced release of glucocorticoids, and the consequent activation of glucocorticoid receptors in fetal hippocampus. Therefore, elucidation of the precise effects of stress-induced $\mathrm{CRH}$ on fetal and neonatal hippocampal neurons requires animal studies.

In the neonatal or infant rat, synthetic CRH has excitatory actions on hippocampal neurons and, in higher doses, has neurotoxic effects. Application of the peptide to hippocampal slices reduces slow afterhyperpolarization [57], enhances synaptic efficacy [58] and primes LTP [31]. In immature hippocampal slices, the peptide enhances the amplitude of evoked CA1 population spikes [59], whereas CRH administration in vivo can lead to prolonged limbic seizures, via activation of $\mathrm{CRF}_{1}$ [41]. The robust actions of exogenous CRH early in life are consistent with the notion that release of endogenous peptide from abundant $\mathrm{CRH}$-expressing hippocampal neurons might mediate the beneficial, as well as the adverse, effects of early-life stress on the hippocampus. An intriguing 'paradox' should be noted: despite its excitatory actions, CRH is expressed in, and released from, neurons with the morphological and neurochemical characteristics of inhibitory, GABAergic interneurons. In addition, CRHimmunoreactive axons form perisomatic 'baskets', which are characteristic of inhibitory neurons and typically associated with inhibitory synapses. The mechanisms of this mismatch (i.e. excitatory actions of a peptide that is released from inhibitory interneurons) are a focus of current investigations.

Does CRH contribute to the beneficial effects of mild early-life stress on hippocampal function? Early-life exposure to the mild stress of a novel environment has been shown to improve memory in the long-term [60]. Interestingly, this manipulation enhances $\mathrm{CRH}$ expression within seconds (at least in the hypothalamus [61]). Later in life, both mild stress and CRH have clearly been shown to influence synaptic plasticity and improve hippocampusdependent memory function [31,58]. In addition, CRH antagonists blocked the effects of acute stress on synaptic plasticity, clearly implicating stress-induced release of endogenous CRH at hippocampal synapses in the mechanisms of these effects [31].

Does CRH contribute to the injurious effects of severe or chronic early-life stress on hippocampal function and integrity? Recent studies showed that administration of picomolar $\mathrm{CRH}$ doses to $\mathrm{P} 10$ rats reproduced the effects of severe stress on hippocampus, provoking progressive deficits in hippocampus-dependent memory functions, which were associated with loss of CA3 pyramidal cells [4]. These deficits occurred also in CRH-treated animals in which plasma glucocorticoids were clamped at low levels, indicating that 'stress levels' of these hormones were not required for these effects [4]. The mechanisms for these persistent and progressive effects of early-life $\mathrm{CRH}$ administration involved chronic dysregulation of the $\mathrm{CRH}$ system, because expression of mRNAs for $\mathrm{CRH}$ and its receptor $\mathrm{CRF}_{1}$ was persistently increased in CA3-hippocampal neurons of the experimental animals. The resulting activation of CRH receptors, coupled with the observed reorganization of excitatory glutamatergic synapses innervating these $\mathrm{CA} 3$ neurons, led to a vicious cycle of progressive neurotoxicity, with consequent functional deficits [4].

\section{Conclusions: novel mechanisms underlying the effects of early-life stress on hippocampal function and integrity}

This review has focused on the molecular chain of events triggered by stress signals early in life, highlighting the crucial role of $\mathrm{CRH}$, which is derived from the placenta in the prenatal human and from uniquely abundant $\mathrm{CRH}$-expressing hippocampal interneurons in the neonatal rat. The data reviewed here indicate that, in both immature human and rat, activation of the synthesis, release and receptors of CRH plays a crucial role in the beneficial and adverse acute 
and long-term effects of early-life stress on the hippocampus. Importantly, they suggest that modulation of these actions of CRH offers an exciting and novel target for preventing the adverse effects of severe early-life stress on the developing hippocampus.

\section{Acknowledgments}

We thank Laszlo Seress and Roland Bender for critical reading and advice on the paper, and Yuncai Chen for help with the figures. Our research is supported by National Institutes of Health grants NS28912 and NS39307 (T.Z.B.) and HD28413 and NS41298 (C.A.S.).

\section{References}

1. McEwen BS. Stress and hippocampal plasticity. Annu Rev Neurosci 1999;22:105-122. [PubMed: 10202533]

2. Pacak K, Palkovits M. Stressor specificity of central neuroendocrine responses: implications for stressrelated disorders. Endocr Rev 2001;22:502-548. [PubMed: 11493581]

3. Sanchez MM, et al. Early adverse experience as a developmental risk factor for later psychopathology: evidence from rodent and primate models. Dev Psychopathol 2001;13:419-449. [PubMed: 11523842]

4. Brunson KL, et al. Long term, progressive hippocampal cell loss and dysfunction induced by earlylife administration of corticotropin-releasing hormone reproduce the effects of early-life stress. Proc Natl Acad Sci U S A 2001;98:8856-8861. [PubMed: 11447269]

5. McEwen BS. Protective and damaging effects of stress mediators. N Engl J Med 1998;338:171-179. [PubMed: 9428819]

6. Kaufman J, et al. Effects of early adverse experiences on brain structure and function: clinical implications. Biol Psychiatry 2000;48:778-790. [PubMed: 11063974]

7. Welberg LA, Seckl JR. Prenatal stress, glucocorticoids, and the programming of the brain. J Neuroendocrinol 2001;13:113-128. [PubMed: 11168837]

8. Brunson KL, et al. Neurobiology of the stress response early in life: evaluation of the concept and the role of corticotropin releasing hormone. Mol Psychiatry 2001;6:647-656. [PubMed: 11673792]

9. Bhutta AT, Anand KJS. Abnormal cognition and behavior in preterm neonates linked to smaller brain volumes. Trends Neurosci 2001;24:129-132. [PubMed: 11182440]

10. Peterson B, et al. Regional brain volume abnormalities and long-term cognitive outcome in preterm infants. J Am Med Assoc 2000;284:1939-1947.

11. Welberg LA, et al. Inhibition of 11 beta-hydroxysteroid dehydrogenase, the foeto-placental barrier to maternal glucocorticoids, permanently programs amygdala GR mRNA expression and anxiety-like behaviour in the offspring. Eur J Neurosci 2000;12:1047-1054. [PubMed: 10762336]

12. Sandman CA, et al. Corticotrophin-releasing hormone and fetal responses in human pregnancy. Ann New York Acad Sci 1999;897:66-75. [PubMed: 10676436]

13. Lightman SL, Young WS. Influence of steroids on the hypothalamic corticotropin-releasing factor and preproenkephalin mRNA responses to stress. Proc Natl Acad Sci U S A 1989;86:4306-4310. [PubMed: 2786213]

14. Herman JP, et al. Evidence for hippocampal regulation of neuroendocrine neurons of the hypothalamo-pituitary-adrenocortical axis. J Neurosci 1989;9:3072-3082. [PubMed: 2795152]

15. Vale W, et al. Chemical and biological characterization of corticotropin releasing factor. Rec Prog Horm Res 1983;39:245-270. [PubMed: 6314446]

16. Yi SJ, Baram TZ. Corticotropin-releasing hormone mediates the response cold stress in the neonatal rat without compensatory enhancement of the peptide's gene expression. Endocrinology 1994;135:2364-2368. [PubMed: 7988418]

17. Walker CD, et al. The pituitary-adrenocortical system of neonatal rats is responsive to stress throughout development in a time-dependent and stressor-specific fashion. Endocrinology 1991;128:1385-1395. [PubMed: 1847856]

18. Dent GW, et al. Rapid induction of corticotropin-releasing hormone gene transcription in the paraventricular nucleus of the developing rat. Endocrinology 2000;141:1593-1598. [PubMed: 10803566] 
19. Hatalski CG, et al. Corticotropin releasing factor mRNA expression in the hypothalamic paraventricular nucleus and the central nucleus of the amygdala is modulated by repeated acute stress in the immature rat. J Neuroendocrinol 1998;10:663-669. [PubMed: 9744483]

20. Liu D, et al. Maternal care, hippocampal glucocorticoid receptors, and hypothalamic-pituitary-adrenal response to stress. Science 1997;277:1659-1662. [PubMed: 9287218]

21. Eghbal-Ahmadi M, et al. Differential regulation of the expression of corticotropin-releasing factor receptor type $2\left(\mathrm{CRF}_{2}\right)$ in hypothalamus and amygdala of the immature rat by sensory input and food intake. J Neurosci 1999;19:3982-3991. [PubMed: 10234028]

22. Levine $S$. Influence of psychological variables on the activity of the hypothalamic-pituitary-adrenal axis. Eur J Pharmacol 2000;405:149-160. [PubMed: 11033322]

23. van Oers HJ, et al. Maternal deprivation effect on the infant's neural stress markers is reversed by tactile stimulation and feeding but not by suppressing corticosterone. J Neurosci 1998;18:1017110179. [PubMed: 9822770]

24. Gunnar MR, et al. Adrenocortical activity and behavioral distress in human newborns. Dev Psychobiol 1988;21:297-310. [PubMed: 3378676]

25. Herman JP, Cullinan WE. Neurocircuitry of stress: central control of the hypothalamo-pituitaryadrenocortical axis. Trends Neurosci 1997;20:78-84. [PubMed: 9023876]

26. Imaki T, et al. Intracerebroventricular administration of corticotropin-releasing factor induces $c$-fos mRNA expression in brain regions related to stress responses: comparison with pattern of $c$-fos mRNA induction after stress. Brain Res 1993;616:114-125. [PubMed: 8358602]

27. Hatalski CG, et al. Neuronal activity and stress differentially regulate hipppocampal and hypothalamic corticotropin releasing hormone expression in the immature rat. Neuroscience 2000;101:571-580. [PubMed: 11113306]

28. McGaugh JL, et al. Involvement of the amygdala in memory storage: interaction with other brain system. Proc Natl Acad Sci U S A 1996;93:13508-13514. [PubMed: 8942964]

29. Pitkänen A, et al. Organization of intra-amygdaloid circuitries in the rat: an emerging framework for understanding functions of the amygdala. Trends Neurosci 1997;20:517-523. [PubMed: 9364666]

30. Joëls M. Corticoid actions in the hippocampus. J Neuroendocrinol 2001;13:657-669. [PubMed: 11489082]

31. Blank T, et al. Priming of long-term potentiation in mouse hippocampus by corticotropin-releasing factor and acute stress: implications for hippocampus-dependent learning. J Neurosci 2002;22:37883794. [PubMed: 11978854]

32. Pitman RK, et al. Investigating the pathogenesis of posttraumatic stress disorder with neuroimaging. J Clin Psychiatry 2001;62:47-54. [PubMed: 11495097]

33. De Kloet ER, et al. Stress and cognition: are corticosteroids good or bad guys? Trends Neurosci 1999;22:422-426. [PubMed: 10481183]

34. Swanson LW, et al. Organization of ovine corticotropin-releasing factor immunoreactive cells and fibers in the rat brain: an immunohistochemical study. Neuroendocrinology 1983;36:165-186. [PubMed: 6601247]

35. Gray TS, Bingaman EW. The amygdala: corticotropin-releasing factor, steroids, and stress. Crit Rev Neurobiol 1996;10:155-168. [PubMed: 8971127]

36. Sakanaka M, et al. Corticotropin releasing factor-like immunoreactivity in the rat brain as revealed by a modified cobalt-glucose oxidase-diaminobenzidine method. J Comp Neurol 1987;260:256-298. [PubMed: 3497182]

37. Yan XX, et al. Corticotropin-releasing hormone (CRH)-containing neurons in the immature rat hippocampal formation: light and electron microscopic features and colocalization with glutamate decarboxylase and parvalbumin. Hippocampus 1998;8:231-243. [PubMed: 9662138]

38. Koob GF, Bloom FE. Corticotropin-releasing factor and behavior. Fed Proc 1985;44:259-263. [PubMed: 3871412]

39. Swiergiel AH, et al. Attenuation of stress-induced behavior by antagonism of corticotropin-releasing factor receptors in the central amygdala in the rat. Brain Res 1993;623:229-234. [PubMed: 8221104]

40. Chen Y, et al. Novel and transient populations of corticotropin releasing hormone-expressing neurons in developing hippocampus suggest unique functional roles: a quantitative spatiotemporal analysis. J Neurosci 2001;21:171-181. 
41. Baram TZ, Hatalski CG. Neuropeptide-mediated excitability: a key triggering mechanism for seizure generation in the developing brain. Trends Neurosci 1998;21:471-476. [PubMed: 9829688]

42. Behan DP, et al. Corticotropin-releasing factor (CRF), CRF-binding protein (CRF-BP), and CRF/ CRF-BP complex in Alzheimer's disease and control postmortem human brain. J Neurochem 1997;68:2053-2060. [PubMed: 9109532]

43. Hedner J, et al. Cerebrospinal fluid concentrations of neurotensin and corticotropin-releasing factor in pediatric patients. Biol Neonate 1989;55:260-267. [PubMed: 2785819]

44. Baram TZ, et al. Brain-adrenal axis hormones are altered in the CSF of infants with massive infantile spasms. Neurology 1992;42:1171-1175. [PubMed: 1318521]

45. Wang W, et al. Elevated corticotropin releasing hormone/corticotropin releasing hormone-R1 expression in postmortem brain obtained from children with generalized epilepsy. Ann Neurol 2001;50:404-409. [PubMed: 11558798]

46. Petraglia F, et al. Evidence for local stimulation of ACTH secretion by corticotropin-releasing factor in human placenta. Nature 1987;328:717-719. [PubMed: 3039377]

47. Goland RS. Biologically active corticotropin-releasing hormone in maternal and fetal plasma during pregnancy. Am J Obstet Gynecol 1988;159:884-890. [PubMed: 2845784]

48. Lowry PJ. Corticotropin-releasing factor and its binding protein in human plasma. Ciba Foundation Symposium 1993;172:108-115. [PubMed: 8387905]

49. Petraglia F, et al. Peptide signaling in human placenta and membranes: Autocrine, paracrine and endocrine mechanisms. Endocr Rev 1996;12:156-186. [PubMed: 8706630]

50. Potter E, et al. Cloning and characterization of the cDNAs for human and rat corticotropin-releasing factor-binding proteins. Nature 1991;349:423-426. [PubMed: 1846945]

51. Robinson BG, et al. Glucocorticoid stimulation expression of corticotropin-releasing hormone gene in human placenta. Proc Natl Acad Sci U S A 1988;85:5244-5248. [PubMed: 2839838]

52. King BR, et al. The regulation of human corticotropin-releasing hormone gene expression in the placenta. Peptides 2001;22:1941-1947. [PubMed: 11754985]

53. Wadhwa PD, et al. The neurobiology of stress in human pregnancy: implications for prematurity and development of the fetal central nervous system. Prog Brain Res 2001;133:131-142. [PubMed: 11589126]

54. Kastin AJ, Akerstrom V. Differential interactions of urocortin/corticotropin releasing hormone with the blood-brain barrier. Neuroendocrinology 2002;75:367-374. [PubMed: 12065889]

55. Brunson KL, et al. Corticotropin (ACTH) acts directly on amygdala neurons to down-regulate corticotropin-releasing hormone gene expression. Ann Neurol 2001;49:304-312. [PubMed: $11261504]$

56. Rotmensch $\mathrm{S}$, et al. The effect of antenatal steroid administration on the fetal response to vibroacoustic stimulation. Acta Obstet Gynecol Scand 1999;78:847-851. [PubMed: 10577612]

57. Aldenhoff JB, et al. Corticotropin releasing factor decreases postburst hyperpolarizations and excites hippocampal neurons. Science 1983;221:875-877. [PubMed: 6603658]

58. Wang HL, et al. Corticotropin-releasing factor produces a long-lasting enhancement of synaptic efficacy in the hippocampus. Eur J Neurosci 1998;10:3428-3437. [PubMed: 9824456]

59. Hollrigel GS, et al. The pro-convulsant actions of corticotropin-releasing hormone in the hippocampus of infant rats. Neuroscience 1998;84:71-79. [PubMed: 9522363]

60. Williams BM, et al. Environmental enrichment: effects on spatial memory and hippocampal CREB immunoreactivity. Physiol Behav 2001;73:649-658. [PubMed: 11495671]

61. Chen Y, et al. Rapid phosphorylation of the CRE binding protein precedes stress-induced activation of the corticotropin releasing hormone gene in medial parvocellular hypothalamic neurons of the immature rat. Mol Brain Res 2001;96:39-49. [PubMed: 11731007]

62. Kretschman HJ, et al. Growth of the hippocampal formation in man. Bibl Anat 1986;28:27-52. [PubMed: 3707511]

63. Khazipov R, et al. Early development of neuronal activity in the primate hippocampus in utero. $\mathrm{J}$ Neurosci 2001;21:9770-9781. [PubMed: 11739585]

64. Gottlieb A, et al. Rodent brain growth stages: an analytical review. Biol Neonate 1977;32:166-176. [PubMed: 603801] 
65. Herschkowitz N, et al. Neurobiological bases of behavioral development in the first year. Neuropediatrics 1997;28:296-306. [PubMed: 9453026]

66. Catalani A, et al. Glial fibrillary acidic protein immunoreactive astrocytes in developing rat hippocampus. Mech Aging Dev 2002;123:481-490. [PubMed: 11796133]

67. Eckenhoff MF, Rakic P. a quantitative analysis of synaptogenesis in the molecular layer of dentate gyrus in the rhesus monkey. Dev Brain Res 1991;17:129-135. [PubMed: 1786637]

68. Diamond A. Rate of maturation of the Hippocampus and the development progression of children's performance on the delayed non-matching to sample and visual paired comparison tasks. Ann New York Acad Sci 1990;608:394-426. [PubMed: 2127514]

69. Nadel, L.; Willner, J. Some implications of post-natal maturation of the hippocampus. In: Chan-Palay, V.; Köhler, C., editors. The Hippocampus-New Vista. Liss; New York: 1989. p. 17-31.

70. Bachevalier J, et al. Limbic-dependent recognition memory in monkeys develops early in infancy. Neuroreport 1993;4:77-80. [PubMed: 8453042]

71. Seress, L. Morphological changes in the human hippocampal formation from midgestation to early childhood. In: Nelson, CA.; Luciana, M., editors. Handbook of Developmental Cognitive Neuroscience. MIT Press; 2001. p. 45-58.

72. Arnold SE, Trojanowski JQ. Human fetal hippocampal development: I. Cytoarchitecture, myeloarchitecture and neuronal morphologic features. J Comp Neurol 1996;367:274-292. [PubMed: 8708010]

73. Bayer SA. The development of the hippocampal region in the rat. I. Neurogenesis examined with ${ }^{3}$ H-thymidine autoradiography. J Comp Neurol 1980;190:87-114. [PubMed: 7381056]

74. Rakic P, Nowakowski RS. The time of origin of neurons in the hippocampal region of rhesus monkey. J Comp Neurol 1981;196:99-128. [PubMed: 7204668]

75. Seress L, Mrzljak L. Postnatal development of mossy cells in the human dentate gyrus: A light microscopic Golgi study. Hippocampus 1992;2:127-142. [PubMed: 1308178]

76. Seress L, Ribak CE. Postnatal development and synaptic connections of hilar mossy cells in the hippocampal dentate gyrus of rhesus monkeys. J Comp Neurol 1995;355:93-110. [PubMed: 7543501]

77. Amaral DG, Dent JA. Development of the mossy fibers of the dentate gyrus: a light and electron microscopic study of the mossy fibers and their expansions. J Comp Neurol 1981;195:51-86. [PubMed: 7204652]

78. Ribak CE, et al. The development, ultrastructure and synaptic connections of the mossy cells of the dentate gyrus. J Neurocytol 1985;14:835-857. [PubMed: 2419523]

79. Herschkowitz N, et al. Neurobiological bases of behavioral development in the second year. Neuropediatrics 1999;30:221-230. [PubMed: 10598832]

80. Hevner RF, Kinney HC. Reciprocal entorhinal-hippocampal connections established by human fetal midgestation. J Comp Neurol 1996;372:384-394. [PubMed: 8873867]

81. Supèr H, Soriano E. The organization of the embryonic and early postnatal murine hippocampus. II. Development of enthorhinal, commissural, and septal connections studied with the lipophilic tracer DiI. J Comp Neurol 1994;344:101-120. [PubMed: 8063952]

82. Ceranik K, et al. Hippocampal Cajal-Retzius cells project to the entorhinal cortex: retrograde tracing and intracellular labeling studies. Eur J Neurosci 1999;11:4278-4290. [PubMed: 10594654]

83. Berger B, et al. Neurochemical development of the hippocampal region in the fetal rhesus monkey. I. Early appearance of peptides, calcium-binding proteins, DARPP-32, and monoamine innervation in the entorhinal cortex during the first half of gestation (E47-E90). Hippocampus 1993;3:279-305. [PubMed: 8353610]

84. Berger B, et al. Human and monkey fetal brain development of the supramammillary-hippocampal projections: a system involved in regulation of theta activity. J Comp Neurol 2001;429:515-529. [PubMed: 11135232] 


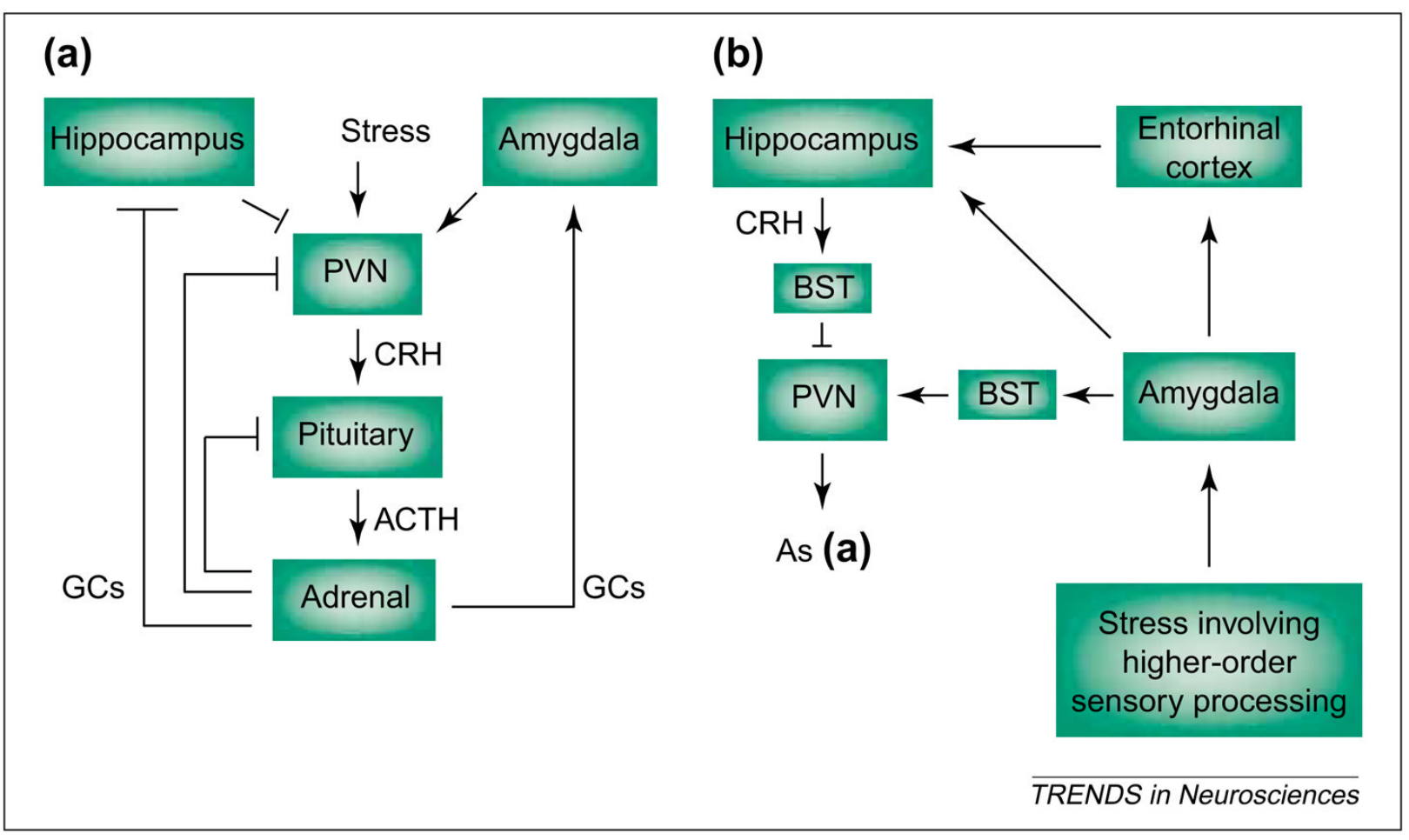

Fig. 1.

Stress-activated pathways include the neuroendocrine hypothalamic-pituitary-adrenal axis (a) and the central, limbic stress-loop (b). (a) 'Physiological' stress signals reach the hypothalamus, causing secretion of corticotropin-releasing hormone $(\mathrm{CRH})$ from neurons of the paraventricular nucleus (PVN). CRH induces release of adrenocorticotropic hormone (ACTH) from the pituitary, and ACTH elicits secretion of glucocorticoids (GCs) from the adrenal gland. GCs cross the blood-brain barrier and activate specific receptors in hippocampus (and other CNS regions) to 'shut off' the neuroendocrine stress response. By contrast, GCs increase CRH mRNA expression in the amygdala, facilitating stress-responses $[19,35]$, whereas pituitary ACTH reduces CRH mRNA levels in the amygdala by direct activation of melanocortin receptors [55]. (b) Stress involving higher-order sensory processing (i.e. with 'cognitive' and/or 'emotional' aspects) activates limbic pathways constituting the more recently elucidated 'central' stress circuit. Stressful stimuli reach the key processor, the central nucleus of the amygdala (ACe), activating the numerous $\mathrm{CRH}$-producing neurons in this region. Locally released $\mathrm{CRH}$ acts on cognate receptors on projection neurons of the amygdala, which convey stress-related information (directly, or indirectly via the entorhinal cortex) to the hippocampal formation. Within the hippocampus, stress-induced release of CRH from interneurons in the CA3 and CA1 pyramidal-cell layers enhances synaptic efficacy and influences memory function. Arrows indicate facilitatory projections but do not imply monosynaptic connections. Blunt-ended lines denote inhibitory feedback loops. Abbreviation: BST, bed nucleus of the stria terminalis. 

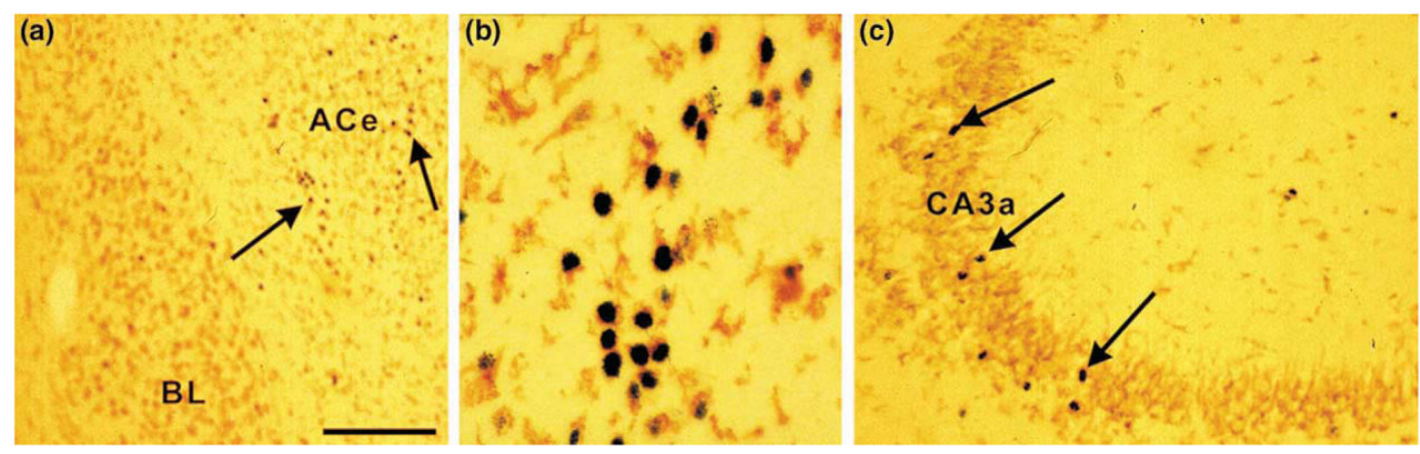

Fig. 2.

Reproducing the effects of stress, administration of corticotropin-releasing hormone (CRH) to immature (10-day-old) rat induces production of Fos protein (black reaction product; arrows) in select populations of neurons in the amygdala $(a, b)$ and hippocampus $(c)$ that bear the $\mathrm{CRF}_{1}$ subtype of $\mathrm{CRH}$ receptor (brown immunoreactivity). Coronal sections from animals perfused $2 \mathrm{~h}$ after $\mathrm{CRH}$ treatment were double-labeled for Fos and $\mathrm{CRF}_{1}$ using standard methods [37,40,61]. CRH induced Fos production (arrows) preferentially in the central nucleus of the amygdala (ACe) $(\mathrm{a}, \mathrm{b})$ and in CA3a hippocampal pyramidal cell layer (c). Higher magnification (b) demonstrates cells of the amygdala double-labeled for the nuclear protein Fos and the membranous $\mathrm{CRF}_{1}$. Scale bar, $100 \mu \mathrm{m}$ for (a,c), $20 \mu \mathrm{m}$ for (b). Abbreviation: BL, Basolateral nucleus of the amygdala. 

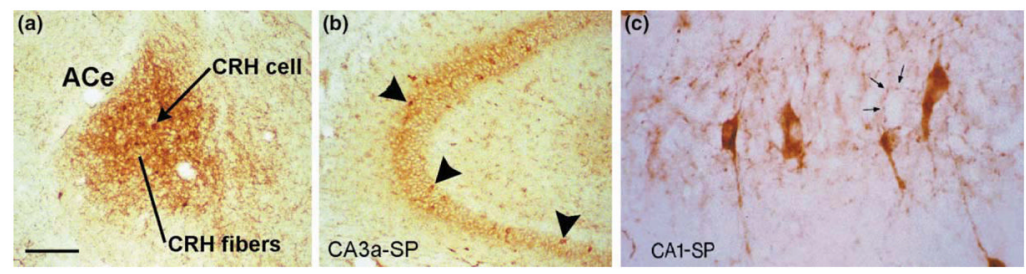

Fig. 3.

CRH-positive neuronal populations are abundant in the amygdala (a) and hippocampus (b, c) of the developing (10-day old) rat. Within the amygdala complex, CRH-immunoreactive cell bodies and fibers populate preferentially the central nucleus of the amygdala (ACe), which is involved in 'processing' of stress signals [29,35]. In the hippocampus, corticotropin-releasing hormone $(\mathrm{CRH})$-producing interneurons reside throughout CA1 and CA3 pyramidal-cell layers [stratum pyramidale (SP); b; arrowheads]. (c) A high magnification of the CA1 subfield demonstrates that $\mathrm{CRH}$-immunoreactive interneurons and axon terminals (arrows) richly innervate pyramidal cell somata, presumably influencing the activity of these neurons. Scale bar, $150 \mu \mathrm{m}$ for (a,b), $25 \mu \mathrm{m}$ for (c). 


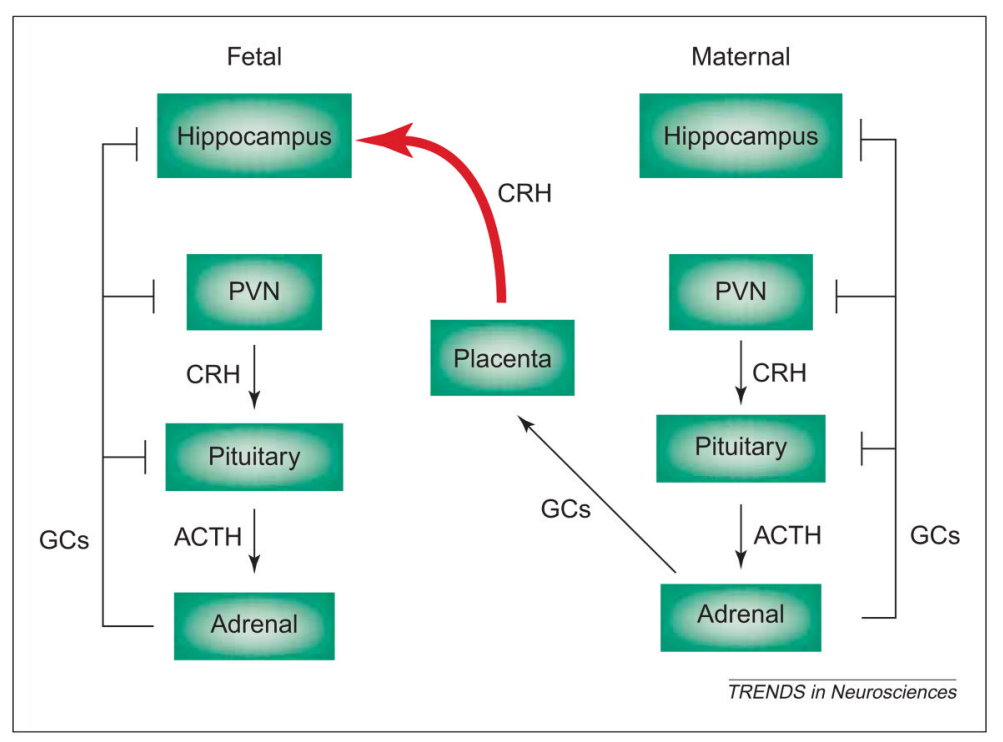

Fig. 4.

In the prenatal human, corticotropin-releasing hormone $(\mathrm{CRH})$ derived from maternal placenta could influence the fetal hippocampus. Sustained stress during pregnancy activates the maternal neuroendocrine stress axis, resulting in increased production and release of placental $\mathrm{CRH}$ into the bloodstream. In contrast to hypothalamic CRH production, which is suppressed by stress-induced glucocorticoids (GCs), CRH-gene expression in placenta is enhanced by GCs, so that maternal stress leads to progressively higher fetal plasma CRH levels. This maternal-origin CRH reaches the fetal brain (red curved arrow) [54], influencing fetal learning and/or memory functions [12,53], presumably by activating hippocampal CRH receptors. Arrows indicate facilitatory pathways but do not imply monosynaptic connections. Bluntended lines denote inhibitory feedback loops. 
Table 1

Selected milestones in hippocampal development of human, rat and primate ${ }^{a}$

\begin{tabular}{|c|c|c|c|c|}
\hline Event & Human & Rat & Primate & Refs \\
\hline \multicolumn{5}{|l|}{ General } \\
\hline Maximal growth velocity & 2-3 Postnatal months & 8-12 Postnatal days & 105-120 Prenatal days & {$[62-65]$} \\
\hline $\begin{array}{l}\text { Hippocampal volume } \\
\text { approximates that of adult }\end{array}$ & 10 Postnatal months & 11-30 Postnatal day & Birth & {$[62,65-67]$} \\
\hline $\begin{array}{l}\text { Hippocampal-dependent } \\
\text { learning and memory } \\
\text { established }\end{array}$ & 4-5 Postnatal years & 15-16 Postnatal days & 1 Postnatal month & {$[68-71]$} \\
\hline \multicolumn{5}{|l|}{ Neuronal formation } \\
\hline Birth of pyramidal cells & First half of gestation & Second half of gestation & First half of gestation & [71-74] \\
\hline Onset: & Before 15 prenatal weeks & $\sim 15$ Prenatal days & 38 Prenatal days & \\
\hline End: & 24 Prenatal weeks & $\sim 19$ Prenatal days & $\sim 80$ Prenatal days & \\
\hline $\begin{array}{l}\text { Birth of granule cells of dentate } \\
\text { gyrus }\end{array}$ & $\begin{array}{l}\text { 70\% Prenatal (majority by } \\
34 \text { weeks) }\end{array}$ & $\begin{array}{l}\sim 85 \% \text { Postnatal (majority } \\
\text { by } 1 \text { postnatal month) }\end{array}$ & $\begin{array}{l}\sim 85 \% \text { Prenatal (majority by } \\
\text { end of } 1 \text { postnatal month) }\end{array}$ & [71-74] \\
\hline Onset & 13-14 Prenatal weeks & $\sim 18$ Prenatal days & $\sim 38$ Prenatal days & \\
\hline End & Throughout life & Throughout life & Throughout life & \\
\hline \multicolumn{5}{|c|}{ Differentiation and synaptogenesis } \\
\hline $\begin{array}{l}\text { 'Thorny excrescences' on } \\
\text { proximal CA3 pyramidal cell } \\
\text { dendrites }\end{array}$ & Postnatal years & 1 Postnatal month & 1 Postnatal year & {$[75-78]$} \\
\hline Onset & 3-7 Postnatal month & $\sim 9$ Postnatal days & Birth & \\
\hline Maturation & 3-5 Postnatal years & 21 Postnatal day & 3 Postnatal months & \\
\hline $\begin{array}{l}\text { Pedunculate spines on distal } \\
\text { CA3 pyramidal-cell dendrites }\end{array}$ & Postnatal years & 1 Postnatal month & 1 Postnatal year & {$[75-78]$} \\
\hline Onset & Birth & 7 Postnatal days & Birth & \\
\hline Maturation & 3-5 Years & 21 Postnatal days & 9-12 Postnatal months & \\
\hline $\begin{array}{l}\text { Peak synapse overshoot in } \\
\text { dentate gyrus }\end{array}$ & 1-2 Postnatal years & 9-14 Postnatal days & 4-5 Postnatal months & {$[67,77-79]$} \\
\hline $\begin{array}{l}\text { Synapse density reaches adult } \\
\text { levels in molecular layer }\end{array}$ & 7-10 Postnatal months & 21 Postnatal days & Birth & {$[65,67,71,78]$} \\
\hline $\begin{array}{l}\text { Period of maximal mossy-cell } \\
\text { differentiation in dentate gryus }\end{array}$ & $\begin{array}{l}\text { 7-30 Postnatal months } \\
\text { (adult-like by } 5 \text { years) }\end{array}$ & $\begin{array}{l}7-14 \text { Postnatal days (adult- } \\
\text { like by } 14 \text { days) }\end{array}$ & $\begin{array}{l}\text { Late prenatal to } 1 \text { postnatal } \\
\text { month (adult-like by } 9-10 \\
\text { months) }\end{array}$ & {$[75,76,78]$} \\
\hline \multicolumn{5}{|l|}{ Afferent input } \\
\hline $\begin{array}{l}\text { Entorhinal cortex to dentate } \\
\text { gyrus }\end{array}$ & 19-20 Prenatal weeks & 17 Prenatal days & 47-56 Postnatal days & {$[80-82]$} \\
\hline $\begin{array}{l}\text { Supramammillary afferents } \\
\text { reach juxtagranular and CA2 } \\
\text { pyramidal-cell layers }\end{array}$ & $\sim 20$ Prenatal weeks & $\begin{array}{l}\text { Presumed first postnatal } \\
\text { week }\end{array}$ & 109-165 Prenatal days & {$[83,84]$} \\
\hline
\end{tabular}

${ }^{a}$ Gestation lasts 270-280, 21 and 165 days in human, rat and rhesus monkey, respectively. 